\title{
Effects of Different Solar Drying Methods on Quality Attributes of Dried Meat Product (Kilishi)
}

\author{
E. S. Apata ${ }^{1}$, O. O. Osidibo ${ }^{1}$, O. C. Apata ${ }^{2}$ \& A. O. Okubanjo ${ }^{3}$ \\ ${ }^{1}$ Meat Science Laboratory, Department of Animal Production, Olabisi Onabanjo University, Yewa Campus, \\ Ayetoro, Ogun State, Nigeria \\ ${ }^{2}$ Department of Home and Hotel Management, Olabisi Onabanjo University, Yewa Campus, Ayetoro, Ogun State, \\ Nigeria \\ ${ }^{3}$ Department of Agriculture and Industrial Technology, Babcock University, Ilishan-Remo, Ogun State, Nigeria. \\ Correspondence: A. O. Okubanjo, Department of Agriculture and Industrial Technology, Babcock University, \\ Ilishan-Remo, Ogun State, Nigeria. E-mail: ebunoluapata2008@yahoo.com
}

Received: May 8, 2012 Accepted: November 13, 2012 Online Published: January 24, 2013

doi:10.5539/jfr.v2n1p80 URL: http://dx.doi.org/10.5539/jfr.v2n1p80

\begin{abstract}
This study was conducted to evaluate the efficiency of four methods of sundrying kilishi after preparation. They included Direct Sundrying Method (DSM) as control, Gujarat Energy Development Agency Method (GEDAM), National Institute of Oceanography Method (NIOM) and Kwatia Drying Method (KDM) each of the methods constituted a treatment viz, A, B, C and D. Meat (Beef) weighing $640 \mathrm{~g}$ was purchased and used for this study. The meat was divided into 4 equal parts of 160 g per treatment. They were sliced into length between 0.17 and $0.20 \mathrm{~cm}$ in thickness and dried between 4 and 5 hours to reduce the moisture to at least $40 \%$ before slurry infusion. The slurry ingredient components were ground and mixed to form a paste. Semi-dried meat were immersed in the slurry for one hour and later stabilized by roasting on charcoal fire for 5 minutes and later dried out in drying media tested in this study. The yield, chemical and sensory properties of kilishi were determined. The results showed that method B gave the highest $(\mathrm{P}<0.05)$ yield of kilishi, chemical attributes as well as sensory properties of kilishi followed by method C. It is suggested that method B and C be developed and produced in commercial quantity for use in drying kilishi in the tropics due to their high efficiency.
\end{abstract}

Keywords: solardrying, kilishi, quality, attributes, methods

\section{Introduction}

In the tropics meat spoils quickly a few hours after the outset of rigor-mortis and post-mortem handling, hence meat needs to be preserved. This is because meat preservation creates an avenue to maintain meat quality (Ikeme, 1990). One of the ways of preserving meat is post-harvest processing. Processed meat is that in which its fresh properties are modified by use of one or more procedures such as grinding, addition of seasoning, heat treatment or drying (FAO, 1995). Processing helps to enhance meat quality as well as elongate its shelf-life (Ogunsola \& Omojola, 2006). Processing also encourages variety and availability of meat, renders it and its products easier to handle, package, distribute and market (Igene et al., 1990). There are many processing methods employed in the preservation of meat which include drying, salting, curing, incorporation of additives, refrigeration and freezing (FAO, 2007). Drying of meat has been in practice for thousands years and mostly used by Nomads and Pastoralists who sort simple means to preserve meat during excess supply (FAO, 1995). Kilishi is one of the processed meat products that is prepared by partially drying of thin sheets of beef in the sun followed by immersion in a slurry of ingredients before a second period of sundrying and brief roasting to stabilize the product (Igene et al., 1990). It is mostly prepared from beef owing to wide preference and acceptability of beef and it is being preserved and sold in open markets as well as being exported (GEDA, 1995). The major thrust in the processing of kilishi is the reduction in moisture content of the meat before infusing the slurry to at least $50 \%$ and after immersion in the slurry to between $30 \%$ and $40 \%$. It had been reported (Kwatia, 1986; NIO, 1993; GEDA, 1995) that solar dryers are fast, save time and reduce human drudgery compared with the traditional sundrying. However (FAO, 1995), reported that drying causes many changes in the quality of meat and meat products. This study was carried out therefore, to evaluate the effects of different solar drying methods on the quality attributes of kilishi. 


\section{Materials and Methods}

Meat samples (Beef) from leg cut used for this study was purchased from butchers at abattoir in Ayetoro Yewa local government area of Ogun State early in the morning to ensure that the meat was relatively hygienic for processing of kilishi.

Meat weighing $640 \mathrm{~g}$ obtained from spent White Fulani cow was properly deboned, trimmed of fat and connective tissues before slicing them into sheets of various lengths between 0.17 and $0.20 \mathrm{~cm}$ in thickness along the fibre direction.

\subsection{Preparation of Infusion Slurry}

Infusion slurry was prepared following the procedures of Igene (1988) using the ingredients as shown in Table 1. The ingredients were ground and mixed thoroughly with clean water to form pasted.

Table 1. Ingredients composition of kilishi infusion slurry

\begin{tabular}{lc}
\hline Ingredient & Percentage in mixture \\
\hline Piper guineense & 0.39 \\
Eugenia caryophyllata & 0.40 \\
Afromomum melegueta & 0.38 \\
Capsicum frustenscen & 4.85 \\
Capsicum annum & 4.85 \\
Thonnigia sanguinea & 0.23 \\
Allium cepa & 11.73 \\
Fagara xanthoxyloids & 0.23 \\
Monodora myristica & 0.59 \\
Zingiber officinale & 2.35 \\
Arachis hypogea & 35.20 \\
Seasoning & 0.14 \\
Salt & 1.88 \\
Sugar & 1.88 \\
Water & 35.20 \\
Total & 100.30 \\
\hline
\end{tabular}

Source: Igene, (1988).

\subsection{Drying of Meat Samples}

The meat $(640 \mathrm{~g})$ was divided into 4 treatment groups of $160 \mathrm{~g}$ per treatment and each represented a drying treatment as follows:

Treatment A $=$ Direct Sundrying Method (DSM) as control

Treatment B $=$ Gujarat Energy Development Agency Method (GEDAM)

Treatment $\mathrm{C}=$ National Institute of Oceanography Method (NIOM)

Treatment $\mathrm{D}=$ Kwatia Drying Method (KDM)

Meat sample dried with DSM were spread on a clean plywood board after slicing and were covered with net to prevent flies. Other meat samples were spread in solar driers according to B, C and D arrangements. The meat samples in each treatment were allowed to dry between 4 and 5 hours until at least $40-50 \%$ moisture loss was obtained according to Omojola et al. (2003). 


\subsection{Infusion of Slurry into Meat and Stabilization of Kilishi}

The semi-dried meat samples were immersed in the slurry for one hour for sufficient uptake of the slurry by the meat samples. They were removed and placed into their respective drying media (dryer) and stationed under the sun between 4 and 5 hours (Omojola et al., 2003).

Kilishi samples were stabilized with heat. The products were placed on charcoal fire for 5 minutes to ensure that the ingredient sticked to meat strips properly (Igene et al., 1990). They were removed from fire and cooled at room temperature $\left(27^{\circ} \mathrm{C}\right)$ and wrapped with clean paper and sealed in polythene bags.

\subsection{Yield of Kilishi Samples}

The percentage yield of kilishi was determined as the weight of the product after drying over the weight of the product before drying multiply by 100 according to Ogunsola and Omojola (2000). Thus:

\subsection{Chemical Analysis of Kilishi}

$$
\text { Yield of kilishi }=\frac{\text { Weight of kilishi after drying }}{\text { Weight of kilishi before drying }} \times 100
$$

Samples of kilishi from 4 treatments were analysed chemically following the procedures of AOAC (2000). Moisture content of the product was carried out by weighing $2 \mathrm{~g}$ of the product from each treatment into a crucible of a known weight and dried at $100-105^{\circ} \mathrm{C}$ for 24 hours in an oven until a constant weight was attained as follows:

Where,

$$
\text { Moisture content }=\frac{\mathrm{W}_{2}-\mathrm{W}_{0}}{\mathrm{~W}_{1}-\mathrm{W}_{0}} \times 100
$$

$$
\begin{aligned}
& \mathrm{W}_{\mathrm{o}}=\text { weight of empty crucible } \\
& \mathrm{W}_{1}=\text { weight of crucible }+ \text { weight sample } \\
& \mathrm{W}_{2}=\text { weight of crucible }+ \text { dried sample }
\end{aligned}
$$

\subsection{Crude Protein}

This was carried out by digesting $2 \mathrm{~g}$ of kilishi sample from each treatment after grounding in a kjeldahl flask and distilled over the Markham apparatus and titrating the distillate with $0.01 \mathrm{~N} \mathrm{HCl}$. The crude protein value was obtained through conversion of nitrogen $(\mathrm{N} \%)$ content of kilishi samples derived by titration with a constant (6.25); thus crude protein was obtained as $(6.25 \times \mathrm{N} \%)$.

\subsection{Ether Extract (Fat)}

Fat content of kilishi samples from each treatment was determined using a soxhlet extractor with a reflux condenser. $2 \mathrm{~g}$ of ground kilishi from each treatment was placed into a thimble and put into the extractor; petroleum ether was poured into the flask. The flask was heated and the solution was allowed to siphon to the flask for at least 10-12 times. The flask containing the oil was weighed and dried in an oven to a constant weight and fat content obtained thus:

\subsection{Ash Content}

$$
\% \text { fat }=\frac{\text { Weight of oil }}{\text { Weight of kilishi sample }} \times 100
$$

This was determined by weighing $2 \mathrm{~g}$ of kilishi samples from each treatment into a weighed crucible and was put into a muffle furnace set between 550 and $600^{\circ} \mathrm{C}$ for 4 hour. The crucible and its content were cooled in a dessicator at room temperature $\left(25-27^{\circ} \mathrm{C}\right)$ and reweighed. The percentage ash was derived thus:

$$
\% \text { Ash }=\frac{\text { Weight of Ash }}{\text { Weight of Kilishi sample }} \times 100
$$

\subsection{Crude Fibre}

This was determined by weighing $2 \mathrm{~g}$ of ground kilishi sample into a flask and $200 \mathrm{ml}$ of $1.25 \% \mathrm{H}_{2} \mathrm{SO}_{4}$ was added and the mixture was heated under reflux for one hour. The mixture was filtered through a Buckner funnel and the residues were washed back into the flask with $200 \mathrm{ml}$ of $0.31 \mathrm{M} \mathrm{NAOH}$. The mixture was heated for another one hour. $2 \mathrm{ml}$ of 180 Amyl alcohol was added and the mixture was filtered through fibre sieve cloth. The residues 
were washed with hot water twice and were finally transferred into a dry weighed crucible. The crucible with the residues was oven dried at $550^{\circ} \mathrm{C}$ for 4 hours. The crucible containing the ash was cooled in a dessicator and reweighed. The percentage crude fibre was obtained thus:

$$
\% \mathrm{CF}=\frac{\mathrm{W}_{1}-\mathrm{W}_{2}}{\mathrm{~W}_{0}} \times 100
$$

Where,

$$
\begin{gathered}
\mathrm{W}_{\mathrm{o}}=\text { Weight of sample } \\
\mathrm{W}_{1}=\text { Weight of oven dried sample } \\
\mathrm{W}_{2}=\text { Weight of ash dried sample } \\
\text { 2.10 Sensory Evaluation of Kilishi }
\end{gathered}
$$

\subsection{Sensory Evaluation of Kilishi}

This was conducted as described by AMSA (1995). A semi-trained 5-member taste panel was used; Kilishi samples from each treatment were cut into pieces in a clean saucer and served to the panelists. They evaluated each of coded Kilishi samples independently of each other and had to rinse their mouth with milk solution before tasting subsequent samples. The panelists evaluated Kilishi samples on a 9-point hedonic scale for colour, tenderness, juiciness, flavour, meatiness and overall acceptability.

\subsection{Experimental Design and Statistical Analysis}

This study was conducted using completely randomized design. Data collected were subjected to Analysis of Variance (ANOVA) using (SAS 2002), while means were separated with Duncan multiple range test of the same system.

\section{Results and Discussion}

Table 1 shows the composition of Kilishi slurry ingredient while Table 2 shows the percentage yield of Kilishi dried between 4 and 5 hours with different solar drying methods. Kilishi samples in treatments A and D dried at 5 hours later than those in treatments $\mathrm{B}$ and $\mathrm{C}$ which got dried up to at least $40 \%$ moisture level within $4 \mathrm{hrs}$ hence, method B $($ GEDAM) had the highest $(\mathrm{p}<0.05)$ drying efficiency followed by method C $(\mathrm{NIOM})$. Kilishi samples dried with methods A (DSM) and D (KDM) had yield lower $(\mathrm{p}<0.05)$ than those dried with methods A and D since it took $5 \mathrm{hrs}$ before they got dried to at least $40 \%$ moisture level. These results revealed that meat and Kilishi samples dried with method B lost their moisture contents quickly to reach the required moisture level of between 40 and $50 \%$. The rate at which meat and Kilishi attained the required level of moisture content showed the efficiency of the drying media (Igene et al., 1990).

Table 3 shows the mean chemical composition of Kilishi dried with different drying media. The results showed that treatments $\mathrm{A}, \mathrm{B}$ and $\mathrm{C}$ had higher $(\mathrm{p}<0.05)$ dry matter, while treatment $\mathrm{D}$ had the least $(\mathrm{p}<0.05)$. This indicated that the samples of Kilishi dried with these media had less moisture content than the sample of the product dried in medium $\mathrm{D}$ and that could affect their quality attributes positively than in sample dried in drying method D. The range of dry matter obtained in this study agreed with those obtained by Badau et al. (1997) and Savic (1994). Treatment B gave the highest $(p<0.05)$ protein content of $72.77 \pm 0.01 \%$ followed by treatment C with $70.73 \pm 0.05 \%$, while treatment $\mathrm{D}$ gave the least $(\mathrm{p}<0.05)$ protein content of $66.83 \pm 0.12 \%$. Since Kilishi dried with medium B had the lowest moisture content, this could make it possible for more protein concentration in the product couple with the fact that the product dried with medium B could have absorbed reasonably high slurry which was also rich in protein, part of which could have added to the protein of the meat to give the product dried in this medium its elevated protein value according to Igene et al. (1993), especially as the medium was observed to be more efficient than others. Sample of Kilishi dried with medium B had lower $(\mathrm{p}<0.05)$ amount of fat content of $10.30 \pm 0.80$ next to treatment A with the lowest $(p<0.05)$ amount $(9.43 \pm 0.60)$. The level of fat content of Kilishi in treatment $\mathrm{B}$ was reasonable better for the product to acquire good flavour, juiciness and consumer acceptability. Most consumers are apathetic to fat consumption but not at reasonable level which they require for palatable meat as the range of fat content obtained in this study fell within range reported by Badau et al. (1997). The ash content was highest $(\mathrm{p}<0.05)$ in sample of Kilishi dried with medium D with $6.20 \pm 1.80 \%$ followed closely by those in treatments B and C while treatment A had the least $(p<0.05)$ ash content. Ash content of any meat or meat product indicates it level of mineral content depending on the product. However the pattern of ash content observed in this study revealed that the higher the slurry infused into the meat during Kilishi preparation, the higher the level of ash content in the product. This indicated that most of the ingredient in the slurry might have lost their mineral contents into the slurry hence into the meat and product, thereby corroborating the report of Elizerbeth (1995) who observed that the ash content of any processed meat would be the content of the muscle 
tissue in addition to that of ingredient used. The ash content values in this study fell within the range reported by the above author.

The value of crude fibre was highest $(\mathrm{p}<0.05)$ in Kilishi dried with medium D followed by medium C and least $(\mathrm{p}$ $<0.05$ ) in media A and B. Meat contains little or no fibre but infusing ingredient slurry into the meat product like Kilishi could increase the level of fibre in the product since the ingredients were of plant origin. The results of crude fibre in Kilishi samples from this study showed that the higher the amount of slurry absorbed by the meat the higher the level of fibre content in the product following the same pattern of ash content of the product. The results of carbohydrate content of Kilishi revealed that treatments A, B and C had higher $(\mathrm{p}<0.05)$ carbohydrate level than in Kilishi dried with medium D. This result could be expected since the dry matter of Kilishi samples dried with these media was very high and lower in treatment D. The substantial part of the carbohydrate contents of the product could have been contributed by the ingredients in the slurry since they are of plant origin, they are high in common sugar because the meat could have virtually no carbohydrate left in it at the end of glycolysis.

The results of the mean sensory characteristics of Kilishi are presented in Table 4. Kilishi samples that were dried with media $B$ and $C$ had higher $(p<0.05)$ colour followed by those in treatment $C$ and $D$. These results could be because of lower levels of moisture content in Kilishi dried with media B and C due to drying efficiency of these media since Kilishi dried with these media could acquire the required level of weight and moisture loss within 4 hours, while treatment A and D tarried till after 5 hours. Colour of any meat or meat product is its visual perception (Omojola et al., 2003) and this depends on the amount of moisture or water held by the meat or meat product. Since the amount of moisture held by Kilishi dried with media B and C was little. Hence, their high colour scores. The flavour scores for Kilishi samples dried with drying media B and C were higher $(\mathrm{p}<0.05)$ than those of Kilishi samples dried with media A and D. Flavour creates the sensation that consumers have when eating and these perceptions rely on sensation of salty, sweetness, sourness and bitterness on the tongue (Wikipediaa, 2007). Flavour depends on an appreciable amount of fat in meat and meat products. The flavour of Kilishi in treatments B and $\mathrm{C}$ were higher probably because, the fat contents of the product dried with these drying media were relatively high and the moisture contents were also low hence high flavour of the product. Another reason for high flavour scores of Kilishi in treatment B and C could be that the slurry contributed most of flavour inducing nutrients into the product since Kilishi dried with in these media had fairly high slurry uptake. The results of sensory properties of Kilishi further showed that tenderness, juiciness, meatiness and overall acceptability scores were higher ( $\mathrm{p}<$ 0.05) in Kilishi dried with media B and C like colour and flavour scores. This could be to the fact that moisture, protein, and fat contents were relatively better in Kilishi dried with two media. Meat and meat products acceptability is as a result of high colour, flavour, tenderness and juiciness of that meat or meat product couple with the level of moisture content inherent in them (Omojola et al., 2003). It was observed in this study that Kilishi samples that were dried with media B and C were very high in those sensory attributes therefore, their acceptability was very high compared with Kilishi samples that were dried with A and D media which had lower sensory attributes hence low consumer acceptability.

Table 2. Percentage yield of Kilishi dried with different solar drying methods between 4 and 5 hours (means \pm s.d.)

\begin{tabular}{lllll}
\hline \multirow{2}{*}{ Variable } & \multicolumn{4}{c}{ Treatments } \\
\cline { 2 - 5 } & $\mathrm{A}$ & $\mathrm{B}$ & $\mathrm{C}$ & $\mathrm{D}$ \\
\hline Weight of Meat $(\mathrm{g})$ & $76.9 \pm 0.10^{\mathrm{b}}$ & $79.7 \pm 0.80^{\mathrm{a}}$ & $72.5 \pm 0.12^{\mathrm{d}}$ & $73.6 \pm 0.17^{\mathrm{c}}$ \\
Weight of slurry (g) & $35.6 \pm 0.05^{\mathrm{c}}$ & $33.7 \pm 0.86^{\mathrm{d}}$ & $46.9 \pm 0.67^{\mathrm{b}}$ & $48.4 \pm 0.89^{\mathrm{a}}$ \\
Weight of Kilishi before drying(g) & $112.5 \pm 0.05^{\mathrm{c}}$ & $113.4 \pm 0.03^{\mathrm{c}}$ & $119.4 \pm 0.01^{\mathrm{b}}$ & $122.0 \pm 0.01^{\mathrm{a}}$ \\
Weight of Kilishi after drying(g) & $54.0 \pm 0.67^{\mathrm{d}}$ & $55.0 \pm 0.62^{\mathrm{c}}$ & $56.2 \pm 0.62^{\mathrm{b}}$ & $67.3 \pm 0.42^{\mathrm{a}}$ \\
Yield of Kilishi(\%) & $48.0 \pm 0.92^{\mathrm{d}^{* *}}$ & $48.50 \pm 0.92^{\mathrm{a}^{*}}$ & $47.07 \pm 0.89^{\mathrm{b}^{*}}$ & $55.16 \pm 0.24^{\mathrm{c} * *}$ \\
\hline
\end{tabular}

abcd: Means on the same row with different superscripts are statistically significant $(\mathrm{P}<0.05)$;

* Kilishi that got dried at $4 \mathrm{hrs}$ and elicited at least 40\% moisture reduction;

**Kilishi that got dried at $5 \mathrm{hrs}$ later before eliciting at least $40 \%$ moisture reduction. 
Table 3. Chemical composition of Kilishi (means \pm s. d.)

\begin{tabular}{lllll}
\hline & \multicolumn{4}{c}{ Treatments } \\
\cline { 2 - 5 } Variable & A & B & C & D \\
\hline Dry Matter (\%) & $9.13 \pm 0.19^{\mathrm{a}}$ & $9.87 \pm 0.07^{\mathrm{a}}$ & $9.70 \pm 0.07^{\mathrm{a}}$ & $8.13 \pm 0.89^{\mathrm{b}}$ \\
Crude Protein (\%) & $68.87 \pm 0.10^{\mathrm{c}}$ & $72.77 \pm 0.01^{\mathrm{a}}$ & $70.73 \pm 0.05^{\mathrm{b}}$ & $66.83 \pm 0.12^{\mathrm{d}}$ \\
Fat (\%) & $9.43 \pm 0.60^{\mathrm{d}}$ & $10.30 \pm 0.80^{\mathrm{c}}$ & $12.67 \pm 0.09^{\mathrm{b}}$ & $14.13 \pm 0.05^{\mathrm{a}}$ \\
Ash (\%) & $3.70 \pm 1.16^{\mathrm{c}}$ & $5.63 \pm 1.02^{\mathrm{b}}$ & $5.83 \pm 1.02^{\mathrm{b}}$ & $6.20 \pm 1.80^{\mathrm{a}}$ \\
Crude Fibre (\%) & $0.13 \pm 2.85^{\mathrm{c}}$ & $0.13 \pm 2.85^{\mathrm{c}}$ & $0.15 \pm 2.58^{\mathrm{b}}$ & $0.17 \pm 2.55^{\mathrm{a}}$ \\
CHO (\%) & $4.00 \pm 1.10^{\mathrm{a}}$ & $4.10 \pm 1.13^{\mathrm{a}}$ & $4.07 \pm 1.16^{\mathrm{a}}$ & $3.05 \pm 1.16^{\mathrm{b}}$ \\
\hline
\end{tabular}

abcd: Means within the same row with different superscripts are statistically significant $(\mathrm{P}<0.05)$.

Table 4. Sensory characteristics of Kilishi (means \pm s. d.)

\begin{tabular}{lllll}
\hline \multirow{5}{*}{ Variable } & \multicolumn{4}{c}{ Treatments } \\
\hline Colour & B & B & C & D \\
Flavour & $6.20 . \pm 1.33^{\mathrm{b}}$ & $7.80 \pm 0.86^{\mathrm{a}}$ & $7.67 \pm 1.10^{\mathrm{a}}$ & $6.31 \pm 1.33^{\mathrm{b}}$ \\
Tenderness & $6.53 \pm 1.06^{\mathrm{b}}$ & $7.25 \pm 0.09^{\mathrm{a}}$ & $7.13 \pm 0.93^{\mathrm{a}}$ & $6.60 \pm 1.06^{\mathrm{b}}$ \\
Juiciness & $5.25 \pm 1.96^{\mathrm{b}}$ & $6.47 \pm 1.28^{\mathrm{a}}$ & $6.25 \pm 1.22^{\mathrm{a}}$ & $5.27 \pm 1.82^{\mathrm{b}}$ \\
Meatiness & $5.21 \pm 1.11^{\mathrm{b}}$ & $6.40 \pm 1.45^{\mathrm{a}}$ & $6.13 \pm 1.81^{\mathrm{a}}$ & $5.23 \pm 2.10^{\mathrm{b}}$ \\
Overall Acceptability & $6.47 \pm 1.06^{\mathrm{b}}$ & $7.80 \pm 0.78^{\mathrm{a}}$ & $7.67 \pm 0.82^{\mathrm{a}}$ & $6.53 \pm 1.02^{\mathrm{b}}$ \\
\hline
\end{tabular}

abcd: Means within the same row with different superscripts are statistically significant $(\mathrm{P}<0.05)$.

\section{Conclusion}

Preservation of meat is very important for it to serve the purpose of supplying the teeming population of the world especially in the developing countries with essential nutrients for maintenance of health. There are many methods of preserving meat which includes processing into different products among which is Kilishi which is dried under the sun after slurry infusion. Direct sundrying however, can affect both the chemical, yield and organoleptic properties of the product therefore development of different methods of drying the product is necessary to evolve a better and more efficient method for preserving Kilishi without mush damage to it. In this study, four methods of sundrying were tested, which included, Direct Sunlight drying, as control, Gujarat Energy Development Agency method, National Institute of Oceanography method and Kwatia drying method. In all, Gujarat Energy Development Agency method proved to be the most efficient, closely followed by the method of National Institute of Oceanography. It is therefore, recommended that Gujarat Energy Development Agency and National Institute of Oceanography methods be developed and commercialized for use in the tropics for their high efficiency in drying Kilishi.

\section{References}

AOAC. (2000). Official Methods of Analysis, $19^{\text {th }}$ edition AOAC Inter; Inc. Washington D.C. pp. 1219.

AMSA. (1995). Research Guidelines for Cookery, Sensory Evaluation and Instrumental Measurement of fresh meat. National Livestock and Meat Board. Chicago IL, U.S.A.

Badau, M. H., Igene, J. O., Collison, E. K., \& Nkamma, L. (1997). Studies on Production, Physicochemical and Sensory Properties of a Standard Kilishi Ingredient Mix Powder. Int. J. Food Sci. Nutri., 48, 165-168. http://dx.doi.org/10.3109/09637489709012589

Elizabeth, B. (1995). Ingredients in Processed Meat Products Paper Presentation. Department of Animal Science and Industry, Kansastate University USA.

FAO. (1995). Development and Promotion of value added products. Project Document, FAO, Rome. 
FAO. (2007). Manual on Meat Cold store Operations and Management. Agriculture and Consumer Protection. FAO Corporate Document Repository FAO, Rome.

GEDA. (1995). Gujarat Energy Development Agency Drying. Retrieved May 9, 2010 from www.geda.org

Igene, J. O. (1988). Lipid, Fatty acid Composition and Storage Stability of Kilishi-A sundried meat product. Trop. Sci., 28, 153-161.

Igene, J. O., Abubakar, U., Akanbi, C. T., \& Negbnebor, A. (1993). Effect of Sodium tripolyphosphate and moisture level on the drying characteristics and yield of Kilishi.

Igene, J. O., Farouk, M. M., \& Akanbi, C. T. (1990). Preliminary Studies on the Traditional Processing of Kilishi. J. Sci. Food, Agric., 50, 89-98. http://dx.doi.org/10.1002/jsfa.2740500110

Ikeme, A. I. (1990). Meat Science and Technology-A Comprehensive Approach (p. 5). Africana-FEP Publishers Ltd, Onitsha, Nigeria.

Kwatia, J. T. (1986). Cassava: Storage, Processing and Utilization. Department of Mechanical Engineering, University of Science and Technology, Kumasi, Ghana.

NIO. (1993). National Institute of Oceanography Goa, Retrieved from www.daenvis.org

Ogunsola, O. O., \& Omojola, A. B. (2006). Qualitative Evaluation of Kilishi Prepared from beef and Pork. Afr. J. Biotech., 7(11), 1753-1758.

Omojola, A. B., Isha, O. A., Adewumi, M. K., Ogunsola, O. O., \& Attah, S. O. (2003). Evaluation of the Effect of various additives on acceptability of Kilishi Trop. J. Anim. Sci., 6(2), 97-101.

SAS. (2002). Statistical Analysis System. SAS Stat. Version 9, SAS Institute Inc. Garry, NC, USA.

Savic, I. V. (1994). Preserving Meat in Developing World Annual Review 10:8. FAO Publication, Rome.

Wikipedia. (2007). Flavour (pp. 1-5). The free Encyclopedia. GNU Free Documentation Licence. The Wikipedia Foundation. Inc. USA. 